\title{
The Shellpot Bridge: A Public/Private Partnership That Worked
}

\author{
RANDOLPH R. RESOR * \\ United States Surface Transportation Board \\ JAMES R. BLAZE \\ ZETA-TECH Associates, Inc., Cherry Hill, NJ \\ DAVID W. CAMPBELL \\ Delaware Transit Corporation, Wilmington, DE
}

\begin{abstract}
The Shellpot Bridge is a 536-foot swing bridge located on a rail freight bypass route around Wilmington, Delaware. When the bridge failed in 1994, Conrail, then the bridge's owner, elected not to repair it due to declining freight volume. The State of Delaware reached agreement with the new rail owner, Norfolk Southern Corporation, to provide funds to repair the bridge, with the railroad to pay tolls to repay the state's investment. Recent volumes of traffic over the bridge indicate that, if traffic continues at its current level, Delaware will realize an annual return of 9.75\% on its investment.
\end{abstract}

\section{Introduction}

\subsection{A brief history of rail service in the northeast United States}

At one time, the New England and Middle Atlantic states were the industrial heartland of the United States and the center of its economy. Boston, New York, Philadelphia and Baltimore were major ports and centers of production. New England produced large quantities of textiles, New York was the center of all sorts of industrial and consumer production, and Philadelphia was known as "the workshop of the world", manufacturing everything from furniture to railroad locomotives.

But as the nation grew, production moved to locations with more land, better access to transportation and a less expensive workforce. This movement took most of the $20^{\text {th }}$ Century to happen but by 1975, textile manufacturing was gone from New England, the largest exports from the Port of New York were scrap paper and rags, and the "workshop of the world", Philadelphia, had seen most of its manufacturing move elsewhere (see Daughen and Binzen, 1999).

\footnotetext{
* Contact Author. United States Surface Transportation Board, 395 E Street S.W., Washington, DC 20423. Email: Randolph.Resor@stb.dot.gov The views expressed here are those of the authors alone and do not reflect the views or policy of the Surface Transportation Board or any other government agency.
} 
The consequences, for workers and for the transportation system, were enormous. The railroads of the region were all in bankruptcy by $1975^{1}$. The U.S. government created the "Consolidated Rail Corporation", a government corporation, to take over ownership of selected rail assets and to attempt to return to profitability as a freight carrier ${ }^{2}$. The "Northeast Corridor", 450 miles of railroad linking Boston, New York, Philadelphia and Washington, was turned over to Amtrak, a passenger rail operator owned by the U.S. government. These actions put nearly all rail transportation in the region, both freight and passenger, into public ownership. However, for freight transportation, the story ended happily. Conrail became profitable in the early 1980s. With more then than $\$ 500$ million in operating income by 1984, Conrail was sold to the public as a stock corporation for more than $\$ 1.5$ billion in 1985. That value excluded the calculated worth of forgone tax loss carry-forwards and also excluded almost $\$ 1$ billion in Conrail cash on hand, as well as future depreciation charges against Conrail assets ${ }^{3}$. The Northeast Corridor (NEC) remained in Amtrak's hands following the sale, although not a moneymaking asset, it carried more than half of all Amtrak riders plus millions of passengers annually on locally operated short-distance trains.

In 1996, two other competing private railroads, Norfolk Southern Corporation and CSX Transportation, bid a total of more than \$10.4 billion for Conrail, which they then split between themselves. ${ }^{4}$ NSC and CSXT now own most freight rail assets in the northeast United States.

\subsection{Public/private partnerships and transportation investment in the United States}

In the $19^{\text {th }}$ Century, some public investments were made in transportation facilities (roads, canals, railroads) but operation was generally left to the private sector. By 1900, most long-distance land transportation was provided by railroads, while roads provided mainly short-distance transportation and were built and maintained by local governments. However, this was all to change in the $20^{\text {th }}$ Century. By 1922, the United States Bureau of Public Roads had been created, following a long campaign to "get farmers out of the mud", and a tax on motor vehicle fuels was dedicated to providing road infrastructure. While the tax was federal and BPR set design standards, the money was actually spent by state governments, who also decided where roads were to be built or reconstructed. The availability of Federal funds led to an orgy of road building during the rest of the century (Goddard, 1994).

The United States is now well supplied with roads but tax revenues are increasingly inadequate to cover both the maintenance of existing roads and the construction of new highways. Freight volume continues to grow, and new types of financing are needed for roads, railroads and other transportation facilities. One possible mechanism is the use of

\footnotetext{
${ }^{1}$ United States Congress, A Review of National Railroad Issues. Office of Technology Assessment: Washington, DC. 1975.

${ }^{2}$ United States Code Title 45 (Railroads), Chapter 17 (Public Law 94-210, Railroad Revitalization and Regulatory Reform Act of 1976)

"Remarks at a White House Ceremony Marking the Sale of the Consolidated Rail Corporation," http://www.reagan.utexas.edu/archives/speeches/1987/040387a.htm

${ }^{4}$ United States Surface Transportation Board, Docket \#FD 33388, CSX corporation and CSX transportation, Inc., Norfolk Southern Corporation and Norfolk Southern Railway Company - control and operating leases/agreements - Conrail Inc. and Consolidated Rail Corporation, July 23, 1998.
} 
public/private partnerships. These are not entirely new in United States history but their use has been growing recently as states and localities find themselves increasingly unable to fund needed transportation projects from bonds and tax receipts (Poole and Samuel, 2006). Public/Private partnerships in transportation finance have taken various forms. Some selected examples of these may be found in Table 1.

Various models have been adopted for these public/private enterprises. New Jersey has implemented two "DBOM" (design, build, operate, maintain) projects, with more under consideration. Both of the projects now operating are rail transit operations ("light rail”). Since light rail generally cannot cover its operating costs from passenger revenues, these projects are analogous to the use of "shadow tolls" in some highway projects. The state contracts with a single private entity to build the project and then operate it for a set period, for a specific subsidy agreed in advance. The private operator assumes the full risk of unforeseen cost increases and revenue shortfalls. At the end of the concession period, the facility reverts to public ownership and (at the option of the state) public operation. By transferring much of the business risk to a private entity, the state hopes to provide transit service at a lower cost. The structure of the agreement also allows the private operator to evade expensive work rules and rates of pay negotiated by public employee unions with the state. How these DBOMs will work out over the long term remains to be seen.

Public/private partnerships have also been undertaken in freight rail (the Shellpot Bridge that is the subject of this paper is, of course, one of them). But the Shellpot project is unusual in that it is structured like a toll highway with a single user, Norfolk Southern Corporation (a freight railroad). As will be seen in later sections of this paper, should rail traffic continue at present levels, the state will recoup its investment with interest. This is unusual for rail projects. The Shellpot Bridge is also an unusual public/private partnership, in that the state assumes the majority of the business risk while also providing financing.

More typical for a freight rail project is the "Heartland Corridor" project, which involves modifying an existing railroad route to handle double-stack ocean containers. This project will cost more than \$200 million, with \$145 million to come from Federal sources, $\$ 14$ million from the states and about $\$ 66$ million from the railroad. There is no specific mechanism to recover the public investment from the railroad (again, Norfolk Southern). Rather, the states hope that economic development made possible by the expanded rail corridor will exceed the cost of the direct public investment. Any business risk on the private portion of the investment is, of course, borne by the railroad ${ }^{5}$.

Highway projects are the most common type of public/private partnership. Table 1 includes three of these. The Fredericton - Moncton Highway was originally planned as a conventional toll road but a change of government resulted in its re-casting as a "shadow toll" road in which government provides the private operator with revenues in proportion to traffic use, in lieu of tolls. The private operator thus bears the full business risk of the project.

\footnotetext{
${ }^{5}$ Eastern Federal Lands Highway Division, "Heartland Corridor Clearance Project," http://www.efl.fhwa.dot.gov/special_projects/heartland-corridor-clearance-project/
} 


\begin{tabular}{|l|l|l|l|l|}
\hline Name & $\begin{array}{l}\text { Scope and } \\
\text { Design }\end{array}$ & $\begin{array}{l}\text { Construction/ } \\
\text { Operation }\end{array}$ & Funding & Notes \\
\hline $\begin{array}{l}\text { Heartland } \\
\text { Corridor (freight } \\
\text { rail), 2007 }\end{array}$ & $\begin{array}{l}\text { Private with } \\
\text { public input }\end{array}$ & Private/Private & $\begin{array}{l}\text { Mix of public and } \\
\text { private funds }\end{array}$ & $\begin{array}{l}\text { Public funds } \\
\text { justified by external } \\
\text { project benefits }\end{array}$ \\
\hline $\begin{array}{l}\text { Indiana Toll } \\
\text { Road (highway), } \\
\text { 2007 }\end{array}$ & $\begin{array}{l}\text { Highway } \\
\text { already existed }\end{array}$ & $\begin{array}{l}\text { No major } \\
\text { construction } \\
\text { involved }\end{array}$ & $\begin{array}{l}\text { Private (bonds } \\
\text { and equity) }\end{array}$ & $\begin{array}{l}\text { Investment repaid } \\
\text { with tolls }\end{array}$ \\
\hline $\begin{array}{l}\text { River Line, NJ } \\
\text { (rail transit), } \\
\text { 2004 }\end{array}$ & $\begin{array}{l}\text { Public (scope) } \\
\text { with private } \\
\text { input to design }\end{array}$ & Private/Private & $\begin{array}{l}\text { Public (“shadow } \\
\text { tolls") }\end{array}$ & $\begin{array}{l}\text { Business risk of } \\
\text { future revenue } \\
\text { assumed by private } \\
\text { operator }\end{array}$ \\
\hline $\begin{array}{l}\text { Shellpot Bridge } \\
\text { (freight rail), } \\
\text { 2004 }\end{array}$ & $\begin{array}{l}\text { Private with } \\
\text { public input }\end{array}$ & Private/Private & $\begin{array}{l}\text { Public (majority) } \\
\text { with private } \\
\text { contribution }\end{array}$ & $\begin{array}{l}\text { Public share } \\
\text { recovered with tolls } \\
\text { over 20-year term }\end{array}$ \\
\hline $\begin{array}{l}\text { Frederickton - } \\
\text { Moncton } \\
\text { Highway, } \\
\text { Canada (2001) }\end{array}$ & $\begin{array}{l}\text { Public with } \\
\text { private input }\end{array}$ & Private/Private & $\begin{array}{l}\text { "Shadow tolls” } \\
\text { provided by New } \\
\text { Brunswick state } \\
\text { government }\end{array}$ & $\begin{array}{l}\text { Originally planned } \\
\text { as a toll highway. } \\
\text { See text }\end{array}$ \\
\hline $\begin{array}{l}\text { Dulles } \\
\text { Greenway, VA } \\
\text { (refinanced } \\
\text { 1999) }\end{array}$ & Public/Private & Private/Private & $\begin{array}{l}\text { Private (bonds } \\
\text { and equity) }\end{array}$ & $\begin{array}{l}\text { Investment repaid } \\
\text { with tolls }\end{array}$ \\
\hline
\end{tabular}

Table 1: Selected examples of different types of recent public/private partnerships in North America

The Dulles Greenway was conceived as a conventional, privately-financed toll highway. However, early tolls were set inappropriately and the concessionaire had to restructure the project's financing in 1999. The road is now returning an adequate investment to the private operator.

The Indiana Toll Road is a private lease of a publicly financed toll road. The original highway was built with public bond funding, with tolls collected to retire the bonds. When the bonds were retired, the State of Indiana retained the tolls to provide funds for operation and maintenance of the road, and for other uses. Realizing that this income stream made the Toll Road attractive to private investors, Indiana entered into a 50-year agreement with Cintra-Macquarie in which the private operators will operate and maintain the highway, increasing tolls in line with inflation. In return, Indiana received a very substantial lump- 
sum payment that will be used for other state transportation projects. Again, the long-term success or failure of this concession remains to be determined.

Private toll-road concessions have, for the most part, been successful in North America. The outlook for "shadow tolls" and for concessions such as the Indiana Toll Road is less clear, in part because of doubt about the public's willingness to pay substantially higher tolls in the future (Peter Samuel, 2007).

Railroad projects have raised even more controversy, since freight railroads in the United States are private, for-profit corporations. However, various studies have found that railroads may have difficulty raising enough capital to keep up with the demand for rail transportation of freight (American Association of State Highway and Transportation Officials, 2003). In this case, public investment in railroads may potentially enable rail to handle a larger share of future freight demand, reducing required investment in highways and also reducing pollution and congestion.

The Shellpot Bridge is unique, however, in that it is a project that benefits a private railroad but it is also one in which the public agency providing the funds may realize a market rate of return on its investment. While the State of Delaware justified its investment in terms of public benefits (improved rail transportation, reduced highway demand), the toll structure agreed to by the state and Norfolk Southern appears to ensure that the project will be a financial benefit to the state as well as to the railroad. The following sections describe how this project came about.

\subsection{The northeast corridor}

The NEC is a multi-track passenger rail corridor between Boston and Washington. It is the only rail corridor in North America with a ridership and train density comparable to those in Europe. More than fifty passenger trains per day operate between New York and Washington, with somewhat less service between New York and Boston. Amtrak has nearly 50\% of the "air/rail" market between Boston, New York and Washington. In addition, a total of six state agencies operate local passenger service over most of the corridor, carrying in total more daily passengers than are handled by Amtrak (Resor, 1999).

Amtrak's NEC once also carried substantial freight service. While the volume of freight service is now less than a third of the 1975 level, both CSXT and NSC still operate freight trains over Amtrak's tracks. The NEC has yards and freight-only bypass tracks at numerous locations to enable the busy railroad to handle both freight and passenger trains. While Amtrak owns the main line tracks, CSXT and NSC now own these freight-only facilities.

The separation of infrastructure ownership and train operation between private corporations and a publicly owned passenger railroad has, predictably, created problems. Amtrak charges high access fees for use of its tracks and the freight carriers have responded by re-routing as much traffic as possible onto alternate routes that they own (and that do not carry passenger trains). With the decline of freight service, some of the freight-only infrastructure has been abandoned or has been allowed to deteriorate. This has had consequences for rail freight service that go beyond the interests of the two private freight carriers and has resulted in the consideration of public investment in rail facilities by several states. 


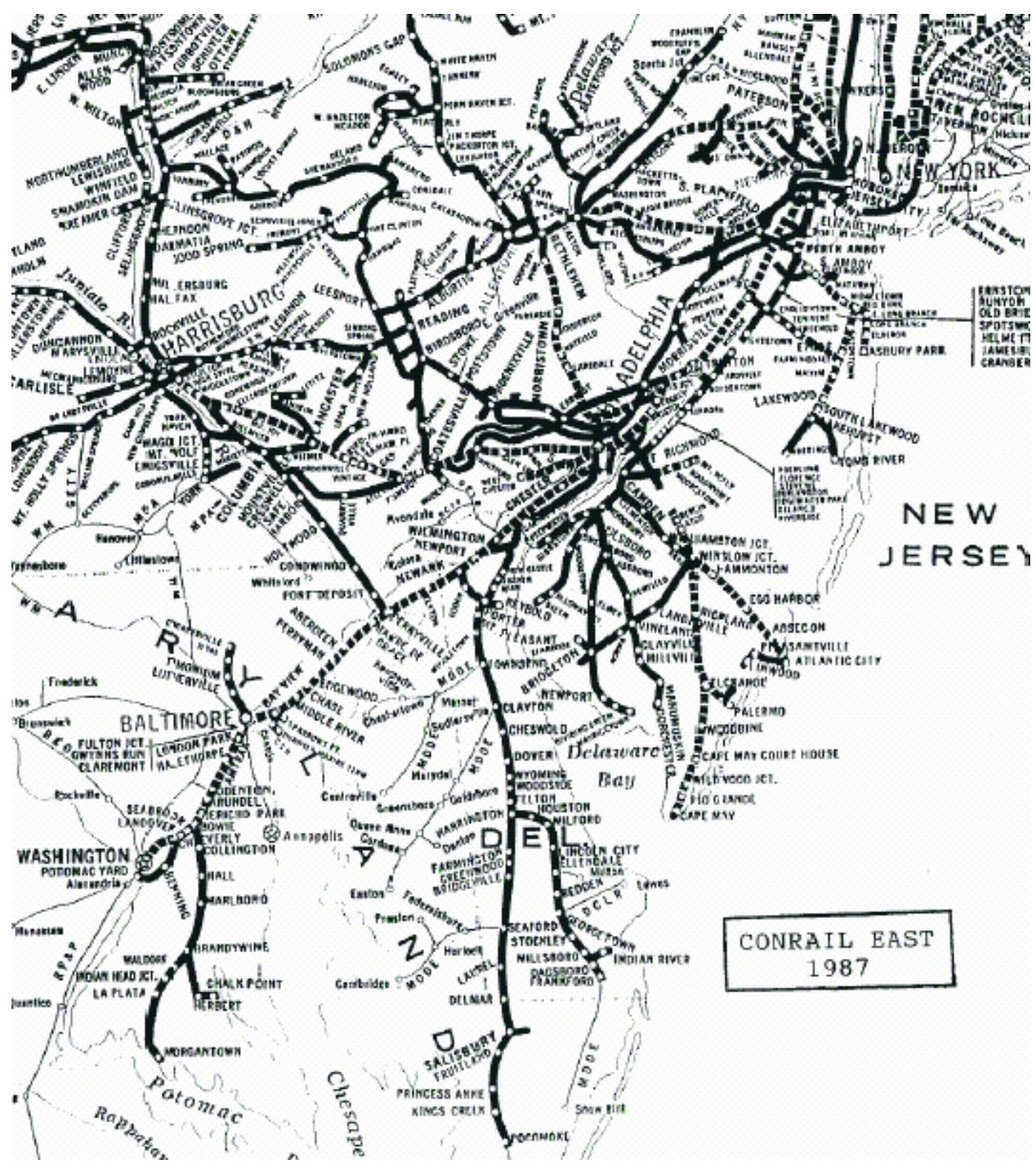

Figure 1: The northeast railroad network (Dashed lines indicate trackage rights)

\section{$1.4 \quad$ MAROP and Delaware}

The Mid-Atlantic Rail Operations Plan (MAROP), developed by a working group comprised of Amtrak, the two freight railroads and planners from six states, is an attempt to address both freight and passenger rail investment in the NEC as a partnership between public and private entities. MAROP has devised a "wish list" of projects that will improve both passenger and freight rail operations in the northeast region ${ }^{6}$. Funding is a major issue; neither the states nor the private railroads can fund the desired improvements by themselves. It is unclear whether the Federal government, which provides $90 \%$ of the

\footnotetext{
${ }^{6}$ I-95 Corridor Coalition, Mid-Atlantic Rail Operations Study Summary Report, April 2002
} 
funding for many highway projects, will contribute to MAROP. It remains to be seen how many of the MAROP projects will in fact happen.

But one small state, Delaware, has taken matters into its own hands. One proposed MAROP improvement was the replacement of the Shellpot Bridge, a bridge over the Christina River in Delaware on a rail freight bypass around the city of Wilmington, DE. The state and Norfolk Southern Corporation (which owns the track in question) reached an agreement to return the bridge to service in a move that benefited both NS and Delaware. How this happened, and the results that have been achieved, is a story that illustrates the value public/private partnerships can produce for all parties.

\section{The Shellpot Bridge project}

\subsection{Location and importance}

The Shellpot Bridge is located east of Wilmington, Delaware on the Christina River. The Shellpot Secondary (its designation when owned by Conrail) carries freight trains between a flyover junction on the NEC at a railroad point called "Bell" in Edgemoor, Delaware and another railroad point on the NEC called "Ragan", south of Wilmington. Total distance from Bell to Ragan is about seven miles. North of Bell on Amtrak's Northeast Corridor, there are four tracks. South of Ragan, there are three. The Shellpot Secondary is one of two originally double-track rail lines through Wilmington, DE. The double-track Amtrak main line carries passenger trains through downtown Wilmington. The Shellpot Secondary, now single track, allows freights to bypass Wilmington to the east and enter Edgemoor Yard (see Figure 2).

Edgemoor Yard serves as a support yard for chemical shippers and other rail customers in the Wilmington area, as well as an intermediate classification point for traffic to and from southern Delaware and the Delmarva Peninsula. In the Conrail era, rail freight traffic moved east from Harrisburg or south from Philadelphia to Edgemoor, where it was switched to local trains for delivery or forwarding to points south. Freight trains from the south could run into Edgemoor from Amtrak's NEC via "Ragan". Both the Port of Wilmington and industries on the New Castle Secondary could be served directly from Edgemoor Yard.

\subsection{The problem}

This operation changed in late 1994, when a pier on the south approach span to the bridge shifted as a train passed over, throwing the track out of alignment (see Figure 3). Conrail, which had seen freight traffic slowly decline on the NEC, chose not to repair the bridge, instead re-routing trains into an alternate yard in Newark, Delaware ("Chrysler Yard"). Edgemoor Yard was essentially abandoned, and local freight to shippers north of Wilmington was handled via Philadelphia or moved through Wilmington's passenger station. Freight for and from southern Delaware, the Delmarva Peninsula (a peninsula divided between Delaware, Maryland, and Virginia - hence the name Delmarva - and separated from land to the west by Chesapeake Bay), and the Port of Wilmington moved from Harrisburg and points west via Perryville, Maryland, thence north on Amtrak's NEC to the Chrysler Yard and then via Porter to the Delmarva Secondary. Most traffic from the south moved north from Washington, DC on Amtrak's NEC to the Chrysler Yard, thence 
via Porter. The line between Ragan and the Shellpot Bridge saw only train movements to and from the Port of Wilmington.

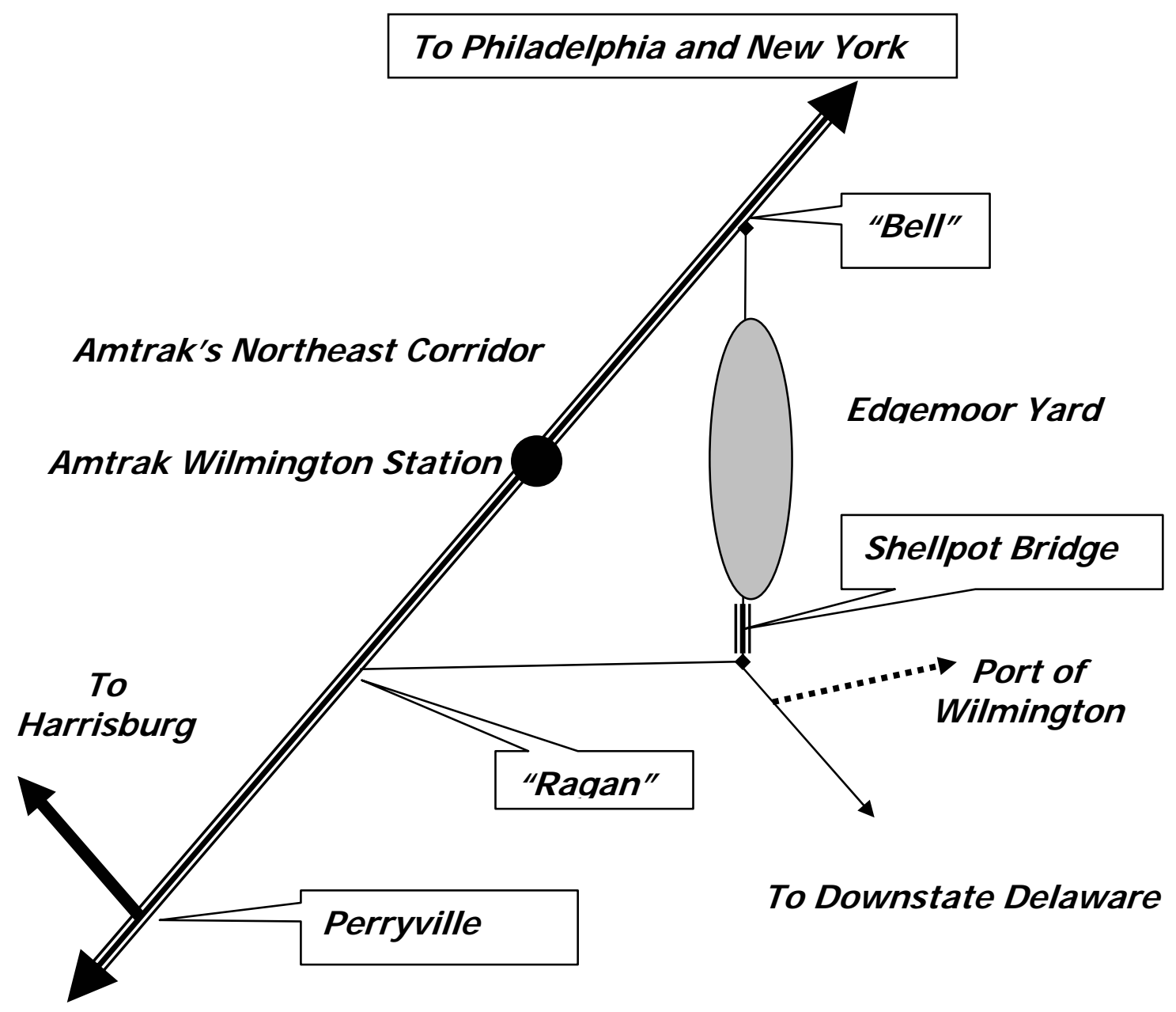

Figure 2: Wilmington area track diagram (not to scale)

The State of Delaware grew concerned that the awkward routing used by Conrail to serve the Port of Wilmington and the southern part of the state represented an economic cost in terms of foregone rail traffic, increased truck traffic, longer transit times and poorer service. The state has a program to subsidize rail service on two "short line" (small) railroads and a general interest in moving more freight traffic by rail rather than on the highway. However, before the state could initiate discussions with Conrail executives, other events intervened.

In 1996, CSX Transportation announced an agreement with Conrail's Board of Directors for CSX to purchase and merge with Conrail. Norfolk Southern Corporation immediately announced its opposition and mounted a hostile tender offer for Conrail stock. The bidding war to capture Conrail shareholders' favor eventually drove the price of Conrail stock to a total value of $\$ 10.4$ billion. The Conrail Board of Directors in March of 1997 finally agreed to allow CSX to reach a separate agreement with NS that would permit 
the two railroads to acquire Conrail as a stock purchase ${ }^{7}$ and then split Conrail between them on the basis of long term leases of the assets. NSC received rights to $58 \%$ of the track mileage and CSXT to $42 \%{ }^{8}$

The two railroads decided what parts of Conrail would go to each. NS received all trackage within the State of Delaware, along with Conrail's “trackage rights"” on Amtrak's Northeast Corridor and the right to serve the Port of Wilmington.

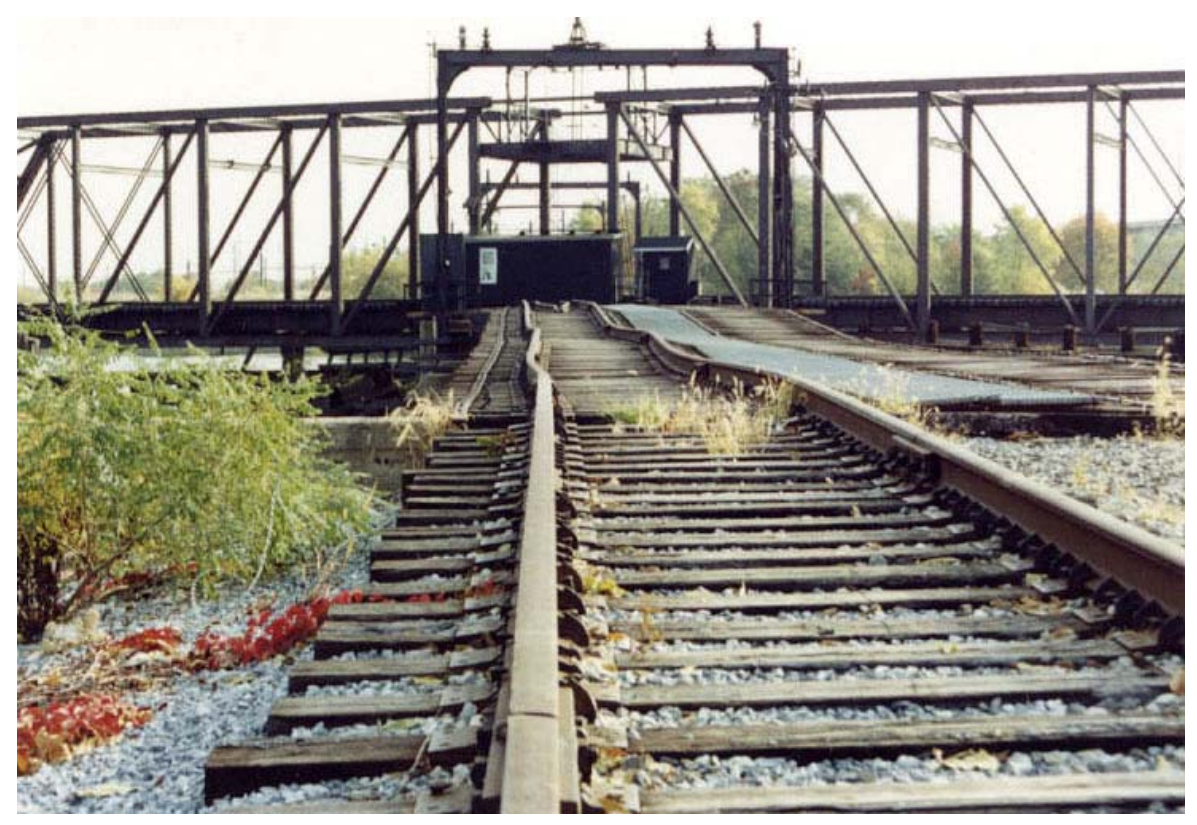

\section{Figure 3: The Shellpot Bridge in 1996}

Railroad mergers and acquisitions require the approval of the Surface Transportation Board (STB), an independent economic regulatory agency organizationally housed within the United States Department of Transportation (safety regulation of the rail industry is handled by the Federal Railroad Administration, one of the modal administrations within USDOT). In implementing the broad public interest standard that governs its review of rail mergers, the STB is directed to consider a variety of factors, including the effect of the transaction on the adequacy of transportation to the public, the public interest of including other carriers in the area, the total fixed charges that would result, the interests of affected rail employees and the competitive impacts of the transaction. During the hearing process that follows a major rail merger application, presentations addressing the relevant criteria are made by the applicant railroads and also by other interested parties, such as labor unions, shippers, states, localities and other railroads. In addition to presenting their views on whether the transaction is in the public interest, these other parties may also seek

\footnotetext{
${ }^{7}$ This stock acquisition approach to a three-party rail merger saved billions of dollars in possible tax consequences by avoiding an outright property acquisition of Conrail.

${ }^{8}$ News release, Surface Transportation Board, May 3, 1998.

http://www.stb.dot.gov/newsrels.nsf/29d1486804c22b1785256e59005e7e87/ab8be6dd79209f8f85256e8300 529cac?OpenDocument

${ }^{9}$ Trackage rights is a term for an agreement under which one railroad runs on track owned by another. Normally, a fee is paid for access - Conrail, and later NS, paid Amtrak a per-car-mile charge.
} 
specific conditions that they want the STB to impose in the event it approves the transaction. The STB reviews the merits of the transaction as a whole and of each particular request for conditions, and issues a decision that addresses the railroads' filings, the interests of the various other participants in the process and, ultimately, the public interest.

\subsection{Post-Merger Developments}

The STB granted permission for CSXT and NSC to acquire Conrail, and "split date" was scheduled for June 1, 1999 (STB, July 23, 1998). During the proceeding, NSC agreed to restore the Shellpot Bridge to service in response to a request from the State of Delaware. In return, Delaware supported the petition of CSX and NSC to purchase Conrail.

Following STB's 1998 approval of the proposed Conrail transaction, both railroads reviewed their capital spending plans in light of detailed surveys of Conrail property. It had originally been estimated by Conrail that the Shellpot Bridge would cost $\$ 6.5$ million to repair. Following an inspection of the bridge, however, NS determined that the expected cost would be more than $\$ 13$ million, about double the original number. NS decided to indefinitely defer reconstruction of the Shellpot Bridge.

The State of Delaware was not pleased with this decision. The state Secretary of Transportation decided that perhaps a case could be made for using public money to reconstruct the bridge. In 2001, he began discussions with NS over terms for sharing the cost of the Shellpot Bridge reconstruction. In late 2001, the Delaware Senate enacted Bill 250, giving the Delaware Secretary of Transportation authority to enter into formal negotiations with NS and also set aside $\$ 4.75$ million as the state's share of the project. Fortunately, the State Senate also gave the Secretary of Transportation authority to return and request additional funding - which turned out to be necessary.

In the spring of 2002, agreement was reached between the state and the railroad. The state would provide $\$ 13.5$ million in funding to reconstruct the bridge and its approaches. The railroad would pay for track reconstruction on tracks connecting the bridge to Edgemoor Yard, to Ragan, to the Port of Wilmington and the Delmarva Secondary. The state's contribution would be recovered through tolls over a 20 -year period with the tolls structured to provide a minimum return to the state of $\$ 4.5$ million even if no rail traffic used the bridge. The toll per car was set to decline as the number of cars increased, giving NS a declining marginal cost for bridge use and thereby encouraging more volume.

\subsection{Structure of the agreement between Norfolk Southern and Delaware}

The agreement between the state and Norfolk Southern was signed on May 3, $2002 .{ }^{10}$ It does not appear to have involved any detailed analysis of expected future traffic. Rather, it was based on recovering most of the state's costs over a 20-year period if traffic over the bridge returned to pre-1994 levels. In addition to providing for reconstruction of the Shellpot Bridge, the agreement also gave Delaware the right to operate passenger trains over any NS track in Delaware "without further rent or user fees". The state has for several years been studying the feasibility of operating passenger trains between Dover, the state

\footnotetext{
10 "Railroad Facilities Improvement and Revenue Participation Agreement”, executed by Nathan Hayward III, Secretary of Transportation, State of Delaware, and H. Craig Lewis, Vice President, Norfolk Southern Corp., May 3, 2002.
} 
capital and Wilmington, the largest city. The Shellpot agreement gives the state authority to do this.

The agreement was crafted to both protect the state's interest and to encourage NS to use the bridge. It specified a minimum annual payment by NS, whether or not the bridge was used, that would have been nearly enough to return the state's original \$4.75 million investment. This minimum annual charge is shown in Table 2.

\begin{tabular}{|l|r|r|}
\hline $\begin{array}{l}\text { Years From } \\
\text { Re-Opening }\end{array}$ & $\begin{array}{l}\text { Minimum } \\
\text { Payment Per } \\
\text { Year }\end{array}$ & \multicolumn{1}{l|}{ Totals } \\
\hline Years 1 through 5 & $\$ 150,000$ & $\$ 750,000$ \\
\hline Years 6 through 10 & $\$ 200,000$ & $\$ 1,000,000$ \\
\hline Years 11 through 15 & $\$ 250,000$ & $\$ 1,250,000$ \\
\hline Years 16 through 20 & $\$ 300,000$ & $\$ 1,500,000$ \\
\hline Total Payments over 20 Years & $\$ 4,500,000$ \\
\hline
\end{tabular}

Table 2: Minimum payment by NS for Shellpot Bridge use

Of course, the minimum payment would not have been nearly adequate to recover the $\$ 13.9$ million actually spent by the state. However, the agreement was structured to require a high initial per-car payment by NS, with the payment declining as the volume of cars increased. This, the state hoped, would give NS an incentive to move an increasing number of cars over the bridge and increase the probability of a positive return to the state.

The schedule of payments per car is shown in Table 3. The first column shows the originally agreed payment schedule. However, the contract provided that, should the state's contribution increase, so would the payment by NS. The adjusted per-car charges reflect amounts NS pays as of 2005.

\begin{tabular}{|l|r|r|}
\hline Annual \# of Cars & Original & Adjusted* \\
\hline Up to 5,000 & $\$ 35.00$ & $\$ 48.03$ \\
\hline 5,000 to 20,000 & $\$ 20.00$ & $\$ 27.45$ \\
\hline 20,000 to 35,000 & $\$ 15.00$ & $\$ 20.58$ \\
\hline 35,000 to 50,000 & $\$ 10.00$ & $\$ 13.72$ \\
\hline More than 50,000 & $\$ 5.00$ & $\$ 6.86$ \\
\hline
\end{tabular}

Table 3: Payments per car for use of the Shellpot Bridge

Note: Rates based on final state cost of $\$ 13,919,820.40$ and agreed to by NS.

The agreement is structured so that NS pays the greater of either the minimum payment or the payment based on actual car volume over the bridge. It has a 20-year term. During the term of the agreement, NS is responsible for maintenance and operation of the bridge (it is a "swing bridge" that must open for river traffic). At the end of the 20-year period, NS retains ownership of the bridge with no need for further payments to the state. However, if NS should decide to abandon service over the bridge after the 20-year term but prior to December 31, 2050, ownership reverts to the State of Delaware, which may arrange for another rail carrier to provide service. 


\section{Reconstructing the Shellpot Bridge}

The bridge itself dates to 1888 and is a registered historic landmark. Therefore, the decision was made early on to refurbish the existing span rather than fabricate a new span and to return the existing span to its historical appearance. The original plan was to remove the swing span in one piece, set it on a barge and move it to Baltimore (about 100 miles or $160 \mathrm{~km}$.) by water for refurbishment by a contractor.

Although the concrete-and-steel approach trestle dates only to 1951, the piers had been undermined by tidal currents and a condition assessment indicated that complete replacement was the most prudent course. The bridge was to be rebuilt as a single-track span (the original bridge carried two tracks), so a single-track concrete pile trestle was designed as a replacement for the existing approaches.

The swing span would be refurbished with a single track centered within the structure rather than the original two tracks. This design reduced the dead load of the bridge and increased its carrying capacity.

In order to restore the bridge to its historical appearance, the operator's cabin was returned to its position atop the center of the swing span (it had been relocated to the bridge deck when the second track was removed). Bridge controls were installed in the cabin but an operator will be needed only in an emergency. The bridge is now remotely operated by a train dispatcher at the NS control center in Harrisburg, Pennsylvania, approximately 80 miles/130 kilometers away. Video cameras provide a view of the river for the dispatcher and the bridge is equipped with alarm horns which sound before it closes for the passage of rail traffic.

The approach spans were demolished and replaced by an open-deck concrete pile trestle. The refurbished main span was set in place once the approach span work, and the replacement of the motors and drive equipment in the center pier had been completed (Figure 4). Note the operator's cabin atop the refurbished span.

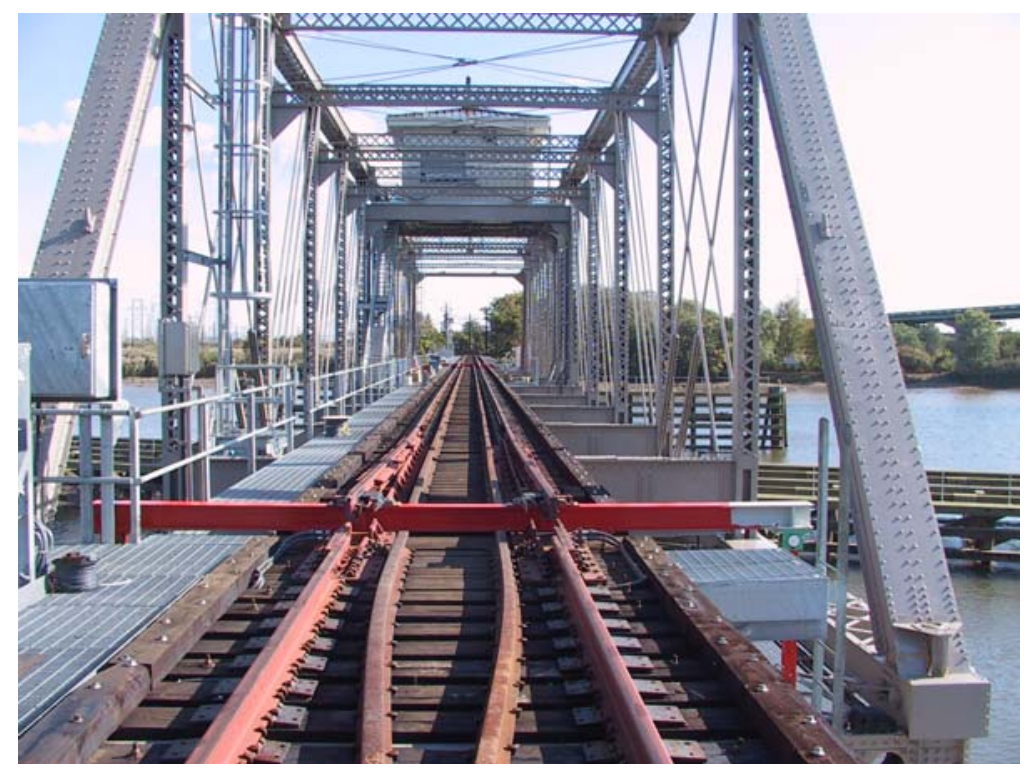

Figure 4: Refurbished main span 
Following extensive testing of the swing machinery, the vessel detection system, the lift rails and other mechanical equipment, the bridge was deemed to be "substantially completed" and was opened to rail traffic with a ceremony at the Port of Wilmington offices on September 2, 2004. Governor Ruth Ann Minner rode across the bridge on a Norfolk Southern locomotive, which then delivered her to the port for the opening ceremonies and lunch. However, work remained to complete the railroad signals protecting the bridge and additional testing of the swing machinery was necessary. The first month of operation was November 2004, when the bridge carried rail traffic for 22 days.

\section{$4 \quad$ Measuring commercial success}

\subsection{Results to date}

The state and Norfolk Southern use an Automatic Equipment Identification (AEI) reader at the north end of the bridge to count the cars and locomotives moving over the bridge (the charge per freight car also applies to locomotives). NS makes annual payments to Delaware based on these car counts. The first payment was made in early 2005, covering use of the bridge in November and December 2004.

Volumes of traffic over the bridge are shown in Table 4. Over 15 months of service, traffic has been averaging more than 7,000 cars per month or nearly 90,000 annually. This is substantially more than were handled in 1994 and prior years, and will yield the State of Delaware a market-rate return on its investment.

\begin{tabular}{|l|r|}
\hline Month & \# of Cars \\
\hline November 2004 (22 days) & 4,108 \\
\hline December 2004 & 6,962 \\
\hline January 2005 & 4,980 \\
\hline February 2005 & 7,225 \\
\hline March 2005 & 6,842 \\
\hline April 2005 & 6,811 \\
\hline May 2005 & 6,758 \\
\hline June 2005 & 7,125 \\
\hline July 2005 & 7,341 \\
\hline August 2005 & 7,611 \\
\hline September 2005 & 7,811 \\
\hline October 2005 & 8,026 \\
\hline November 2005 & 8,138 \\
\hline December 2005 & 8,088 \\
\hline January 2006 & 8,137 \\
\hline Total to Date & 105,963 \\
\hline Monthly Average & 7,064 \\
\hline
\end{tabular}

Table 4: Cars and locomotives over Shellpot Bridge, fifteen months of service 
Total revenue collected by the State of Delaware during 2004 (for the months of November and December, plus some traffic in October) was $\$ 384,811.50$ or $2.8 \%$ of the total expended on the bridge project by the state. During the 12 months of calendar 2005, 98,976 cars and locomotives moved over the bridge, and Norfolk Southern's total payment to Delaware was $\$ 1,502,375.36$. Assuming traffic continues at this level for the twentyyear term of the contract, Delaware will realize a total revenue of more than \$30 million, a very nice return on its $\$ 13.9$ million investment. This revenue stream equates to nearly an $11 \%$ annual return on investment for the state. This is a commercial rate of return although it remains possible that Norfolk Southern may have had higher-yielding projects on which to spend its limited investment capital.

Figure 5 shows the trend in bridge usage. It appears to have leveled at about 8,000 cars and locomotives per month.

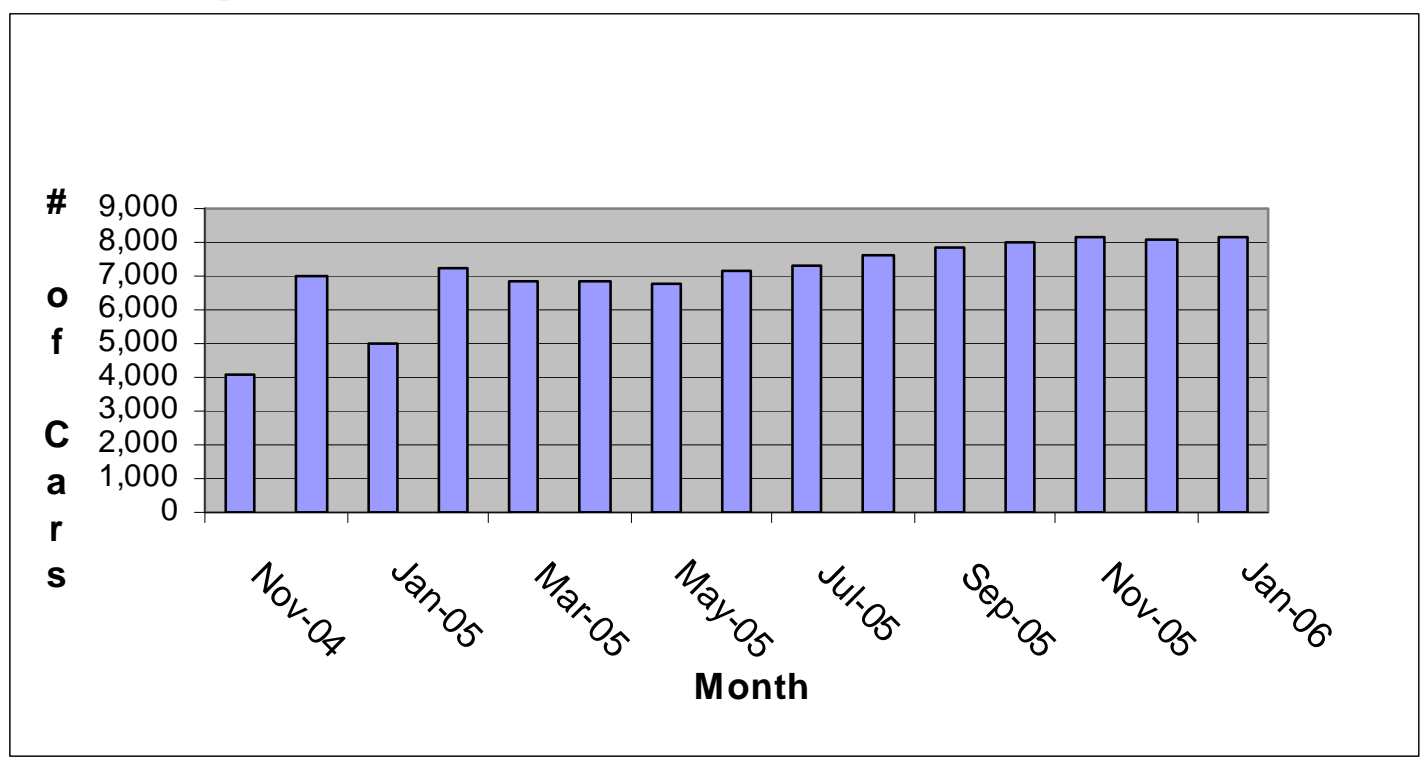

Table 5: Usage of Shellpot Bridge, fifteen months of service

\subsection{Conclusions from the case study}

The Shellpot Bridge is an unusual public/private partnership in several ways:

- It is a railroad project, rather than a highway project. Public investment in rail facilities, especially freight rail is unusual in the United States, though it may be becoming more common

- Most of the few public investments in rail facilities to date have been justified by the presumed external (public) benefits. The Shellpot Bridge involves direct payments by Norfolk Southern to the state for use of the bridge

- It appears, based on current usage, that the tolls will repay the state's investment with interest. In the meantime, Norfolk Southern has been able to reduce the time and cost involved in providing rail service to the state of Delaware, notwithstanding the tolls the railroad must pay.

There are some other less obvious benefits for the railroad. Norfolk Southern avoids making a long-lived investment (bridges typically are designed for an 80-year life) that 
will remain on its balance sheet even if business conditions change and the bridge is no longer useful. NS also sees the cost of the bridge converted from a fixed charge to a variable cost. Typically, the costs of railroad competitors (especially trucks) are close to $100 \%$ variable. Railroads, with a proportion of fixed costs close to $50 \%$, are thus vulnerable to economic downturns since fixed costs must be covered regardless of traffic levels. NS is now insulated against most business risk because if the railroad no longer needs to use the Shellpot Bridge, it no longer must pay the cost (except for the minimum annual payment).

The State of Delaware is protected as well since with the minimum payment requirement, it will recover a significant part of its investment even if the bridge is used for less than 20 years. At the end of the 20-year period, if NS does not need the bridge, its ownership transfers to the state which may engage another railroad to operate over it.

Finally, NS can use the \$13.9 million not spent on the Shellpot Bridge for investments elsewhere on its system.

Nationwide, these sorts of public/private partnerships may offer great benefits for the private freight railroad industry. Traditionally very capital-intensive, the industry has not in recent years been able to earn a return equal to the cost of capital, thus even some promising investments to add capacity or relieve bottlenecks have not been made.

Recent traffic increases have enabled railroads to raise rates and earnings have increased as well. But business risk remains an inhibitor of investment since no one can forecast how long the good times may last. Transferring at least part of the business risk for long-lived investments to the public sector, as in the Shellpot project, can produce significant benefits for all parties.

While the Shellpot Bridge is not a project of the scope of the Alameda Corridor in Los Angeles (a new 25-mile freight railroad line, much of it below ground level, built with both public and private money), it is a good example of how public intervention can obtain an improvement to the transportation infrastructure that would not have otherwise been undertaken by a private railroad. The completion of the Shellpot Bridge has benefited the railroad, the state and rail shippers.

\section{$5 \quad$ References}

Daughen, Joseph and Peter Binzen (1999) The Wreck of the Penn Central. Beard Books: Frederick, MD.

Goddard, Stephen B. (1994) Getting There: The Epic Struggle Between Road and Rail in the $20^{\text {th }}$ Century. University of Chicago Pres: Chicago.

Poole, Robert and Peter Samuel (2006) “The Return of Private Toll Roads,” Public Roads, March/April, US Department of Transportation, Federal Highway Administration, Washington, DC.

Randolph R. Resor (1999) "Should Amtrak Survive as a National Rail System?” Transportation Quarterly, vol. 53, \#1, pp. 93 - 108. 
Samuel, Peter (2007) “The Role of Tolls in Financing $21^{\text {st }}$ Century Highways,” Policy Study 359, The Reason Foundation: Washington, DC. 